\title{
FACTORS THAT INFLUENCE THE RELATIONSHIP BETWEEN CUSTOMER INFORMATION QUALITY AND SALESPERSON PERFORMANCE
}

\section{ČIMBENICI KOJI UTJEČU NA ODNOS IZMEĐU KVALITETE INFORMACIJA O KORISNICIMA I POSTIGNUĆA PRODAJNOG OSOBLJA}

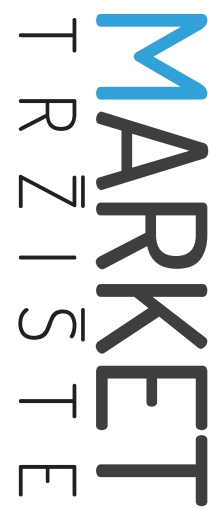

Preliminary communication

\section{Ida Bagus Nyoman Udayana a , Prayekti ${ }^{\text {, Eliya Ardyan }}$}

a Universitas Sarjanawiyata Tamansiswa, Jl, Kusumanegara No. 121, Yogyakarta 55165, INDONESIA, e-mail: ibn.udayana@yahoo.co.id

b Universitas Sarjanawiyata Tamansiswa, Jl, Kusumanegara No. 121, Yogyakarta 55165, INDONESIA, e-mail: yekti_ust@yahoo.co.id

c Sekolah Tinggi Ilmu Ekonomi Surakarta, Faculty of Economics and Business, Slamet Riyadi Makamhaji No. 435, Kartasura, Sukoharjo, Central Java, INDONESIA, e-mail: ardyan.sbs@gmail.com

\begin{abstract}
Purpose - The aim of this research study is to develop the concept of customer information quality in the context of health insurance companies. A research model is proposed to explain how salesperson performance is developed through improved customer information quality. This is important as the awareness of health among people in Indonesia is increasing.
\end{abstract}

Design/Methodology/Approach - The research model was empirically tested on a sample of 450 salespeople in the health insurance sector.

Findings and implications - Results revealed that customer information quality leads to a linkage between the adaptive selling and salesperson performance. Communication ability and trustworthiness have a significantly positive impact on salesperson performance. Managerial Implication: Salesperson performance can be improved through the ability of salespersons to adapt when interacting with customers. Customer information quality can be improved by always building long-term relationships with customers.

\section{Sažetak}

Svrha - Cilj je istraživanja razviti koncept kvalitete informacija o korisnicima usluga u kontekstu poduzeća koja pružaju usluge zdravstvenog osiguranja. Predložen je istraživački model da bi se objasnilo kako se poboljšanom kvalitetom informacija o korisnicima razvijaju postignuća prodajnoga osoblja. To je važno jer u Indoneziji sve više raste svijest ljudi o zdravlju.

Metodološki pristup - Istraživački je model empirijski provjeren na uzorku od 450 prodavača u sektoru zdravstvenog osiguranja.

Rezultati i implikacije - Rezultati pokazuju da kvaliteta informacija o korisnicima dovodi do povezanosti između prilagođavanja prodaje i postignuća prodavača. Sposobnost komunikacije i pouzdanost imaju značajan, pozitivan utjecaj na postignuća prodavača. Menadžerska implikacija Postignuće prodavača može se poboljšati kroz sposobnost prilagodbe prodavača za vrijeme interakcije $s$ korisnicima. Zauzvrat, kvaliteta informacija o korisnicima može se poboljšati trajnom izgradnjom dugoročnih odnosa s njima. 
Limitations - The data analyzed from the perspective of salespersons could be expanded to also include those available from the perspective of the sales manager, thus making them two-sided. In addition, this study involves a cross-sectional design, which might be applied to research over a longer term.

Originality - As the concept of customer information quality in salespersons is still poorly understood, there is a need for theoretically based research of this concept. This paper expands the knowledge in the area of relationship marketing by presenting a research model that introduces the development of customer information quality.

Keywords - customer information quality, salesperson performance, adaptive selling, communication ability, trustworthiness
Ograničenja - Analizirani podatci iz perspektive prodajnog osoblja mogli bi se proširiti uključivanjem podataka iz perspektive prodajnog menadžera, što bi ih učinilo dvostranim. Osim toga, studija koristi krossekcijski dizajn istraživanja koji bi se mogao primijeniti na dugoročno istraživanje.

Doprinos - Koncept kvalitete informacija o korisnicima kod prodajnog osoblja još uvijek nije dobro razumljiv. Stoga postoji potreba za teorijski utemeljenim istraživanjem ovoga koncepta. Rad obogaćuje postojeće znanje u području marketinga odnosa i suradnje predstavljanjem modela koji uvodi razvoj kvalitete informacija o korisnicima.

Ključne riječi - kvaliteta informacija o korisnicima, postignuća prodajnog osoblja, prilagodljiva prodaja, komunikacijska sposobnost, pouzdanost 


\section{INTRODUCTION}

For some time now, salespersons have played an important role in companies (Ahearne, Gruenb \& Jarvisc, 1999; Basir, Ahmad \& Kitchen, 2010; Tawinunt, Phimonsathien \& Fongsuwan, 2015). In the new global economy, they can create a competitive advantage and a good critical market intelligently. They are also believed to have the ability to fully understand the needs and desires of their customers and will therefore be able to overcome any problems faced by the customers to ensure their satisfaction. Customer satisfaction may be reflected in their willingness to repurchase a company's product, their good recommendation for the product, and rare complaints about such products.

A good critical market intelligently deals with ethical activities to obtain important information on competing product development and conditions in the marketing environment. This important information is susceptible to changes in the customers' tastes, and changes in purchasing patterns. A salesperson can talk directly to customers, suppliers, and distributors. Salespersons can analyze competitors by buying competing products, following product links, viewing exhibitions, and proposing competing advertisements.

Moreover, salespersons are people who interact with potential customers (Kim \& Kim, 2014; Lee \& Dubinsky, 2017; Simintiras \& Cadogan, 1996), share values (Gillis, Pitt, Robson \& Berthon, 1998; Naylor \& Frank, 2000), and connect (Amyx, Bhuian \& Shows, 2016; Drollinger \& Comer, 2012; Yu \& Tung, 2014) with customers. These salesperson are intended to maintain the trust of the customers (Twing-Kwong, Albaum \& Fullgrabe, 2013; Yu \& Tung, 2014). Some important factors pertaining to salespersons are adaptive selling (Limbu, Jayachandran, Babin \& Peterson, 2016; Singh \& Das, 2013), and the customer information quality. Thus, as the performance of salespersons is likely to have an impact on companies, it is necessary to develop and empower the salesperson based on the companies' capa- bility (Ahearne \& Jones, 2008; Yao, Chen \& Cai, 2013).

Furthermore, information also plays a crucial role for a company. Currently, managers receive a lot of irrelevant and unreliable information (Gelle \& Karhu, 2003). In terms of the phenomenon of "garbage in, garbage out", the quantity of customer information will influence managerial decisions. A piece of information can obviously be useless unless it is not well managed to the company's benefit (Hu, Huang, Kuse, Su \& Wang, 1997). Unreliable information may result in improper decision-making and performance. Many companies make use of various technologies to collect, save, and analyze information (Madnick, Wang, Lee \& Zhu, 2009); one of such technologies is the CRM system (Chuang \& Lin, 2013). The system will support companies to gather information fast (Chen \& Popovic, 2003).

It is, then, well noted that the success of employees in delivering a good performance is influenced by a number of determining factors. One of them, the ability to communicate, is also regarded as an important factor in accomplishing a salesperson's tasks successfully (Abdul-Hafez \& Al-Nady, 2016). Good communication ability may support the capability of the salesperson to build customers' trust in the offered products. In fact, customers' trust is a result of a long process that takes time (Agnihotria \& Krush, 2015; Yulin et al., 2014). The capability of salespersons to adapt well during their interactions with customers will result in good performance, leading to an increase in sales.

Considering the role of salespersons within an organization or a company to be important in terms of human resources, it merits further research. It is necessary to investigate how salespersons as the spearhead of a company affect the success of a company and, consequently, how their sales competence should be improved in order to improve sales performance. Due to those reasons, salespersons should get more attention from company owners, as well as scholars.

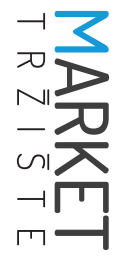




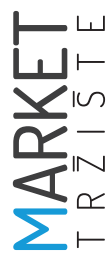

Meanwhile, some inconsistencies between the results of research on adaptive selling and the performance of salespersons still exist. Several prior research studies found that adaptive selling highly influences the salesperson's performance (Kidwell, McFarland \& Avila, 2007; Singh \& Das, 2013; Singh \& Das, 2011; Kidwell et al., 2007; Pettijohn, Schaefer \& Burnett, 2014). On the other hand, the results of other related research have shown that adaptive selling has no positive impact on the performance of sales staff (Abed \& Haghighi, 2009; Markose, 2011; Bolander, Satornino, Hughes \& Ferris, 2015). This research study, however, investigates the factors that influence the quality of customer information in correlation to salesperson performance. Initially, it examines the importance of the role of salespersons in increasing company success before discussing the factors that influence the performance of salespersons; the variables include adaptive selling, the quality of customer information, communication skills, and trustworthiness. This is based on a view that the salespersons who possess good competences in adapting and interacting with customers as well as good communication skills might find it easier to build customer trust and, therefore, have the potential to improve their own performance.

This research begins with the importance of the role of salespersons in increasing the success of the company. Many factors may influence the salesperson's performance. The variables include adaptive selling, quality of customer information, communication skills, and trustworthiness. Salespersons who have good competence in terms of adaptation when interacting with customers, accompanied by good quality communication and can build consumer trust, are presumed to have a potential to improve their performance.

\section{LITERATURE REVIEW}

\subsection{Adaptive selling behavior}

Adaptive selling behavior is one of the most important capabilities for a salesperson to acquire and involves an adjustment (Weitz, Sujan \& Su- jan, 1986). Pettijohn, Pettijohn and Keillor (2000) explain that an effective selling occurs when salespersons are able to adapt to their customers. A salesperson should understand that every customer has different needs and beliefs (Spiro \& Weitz, 1990) and must also be motivated to decide on adopting an appropriate approach to customers. Every customer has his/ her own characteristics and uniqueness that salespersons should pay attention to (Chai, Zhao \& Babin, 2012) in order to rearticulate a positive impact on selling performance. Adaptive selling allows vendors to customize the products to fit the customers' needs and preferences (Singh \& Das, 2013). Positive perceptions by customers of adaptive selling behavior will have an impact on increasing their confidence (Guenzi, De Luca \& Spiro, 2016). Hence, adaptive selling behavior must also be based on a sense of empathy for customers in which a salesperson should understand and respond emotionally to them (Limbu et al., 2016).

\subsection{Customer information quality}

The quality of information about customers is crucial for a company. For this very reason, salespersons must be able to gather quality information about their customers. One of the skills related to information quality concerns how to manage the most important part of information overload (Setia, Venkatesh \& Joglekar, 2013). The term quality information refers to valuable information, instead of its quantity; therefore, it emphasizes the quality and nature of the information (Zhou \& Benton Jr., 2007). The quality of information is measured by considering its timeline, accuracy, and accessibility (Pankaj Setia \& Joglekar, 2013) dimensions. Complete and comprehensive information is very helpful for sales managers to make selling decisions. In addition, the accuracy of information is characterized by its correctness, and having fewer errors. The accuracy level determines the information quality through which an approach is properly used to highlight a more customer-focused orientation. 


\subsection{Trustworthiness}

Customers' trust is an important thing that a company should create and maintain (Schwepker \& Good, 2012). Companies can create trust to pave the way for potential selling performance. The integrity of employees and trust are at the heart of the quality of management system within a company. Managers who can maintain customers' trust through employee integrity urgently support the company's mission to offer its products to the open market (Adewale, Yusuf, Mat Ghani, Meera \& Manap, 2012). Fair and honest treatment of customers can increase their confidence in a company. Companies must therefore be honest to customers in terms of product strengths and weaknesses, so that customers can anticipate them well (Cheung, Yiu \& Lam, 2013).

\subsection{Salesperson performance}

The performance of salespersons is crucial for companies because they contribute to the sales targets that have been determined (Singh $\&$ Koshy, 2010). These targets are measurable and realistic to achieve. The salesperson performance can be based on sales quotas and comparative performances in their departments (Babakus, Cravens, Grant, Ingram \& LaForge, 1996). It can also be viewed from the perspective of sales targets and the abilities of salespersons to increase market shares (Behrman \& Perreault, 1982; Singh \& Das, 2013) and to achieve goals (Brown \& Peterson, 1994). Weitz and others (1986) explain that the rewarded desire is the salesperson's motivation to achieve such performance that will ultimately have an impact on the company's performance. For this reason, companies should encourage salespersons to outperform.

\subsection{Communication ability}

Salespersons are required to have communication skills to maintain good relations with customers (Erikssona, Bergströma, Carlssona \& Harteliusa, 2014). Building good relations with customers requires a good communication strategy. A good strategy formulation involves more roles of salespersons who are the frontline in communicating with customers. The quality of information can give rise to customers' trust (Thomas, Zolin \& Hartman, 2009). In addition, the availability and benefits of information can produce better information quality, in turn affecting customers' trust. Quality forms of communication are manifested in good behavior towards customers, and maintaining a long-term, mutually beneficial cooperation. Openness can improve the quality of communication with customers that leads to customers' trust.

FIGURE 1: A conceptual model of hypotheses

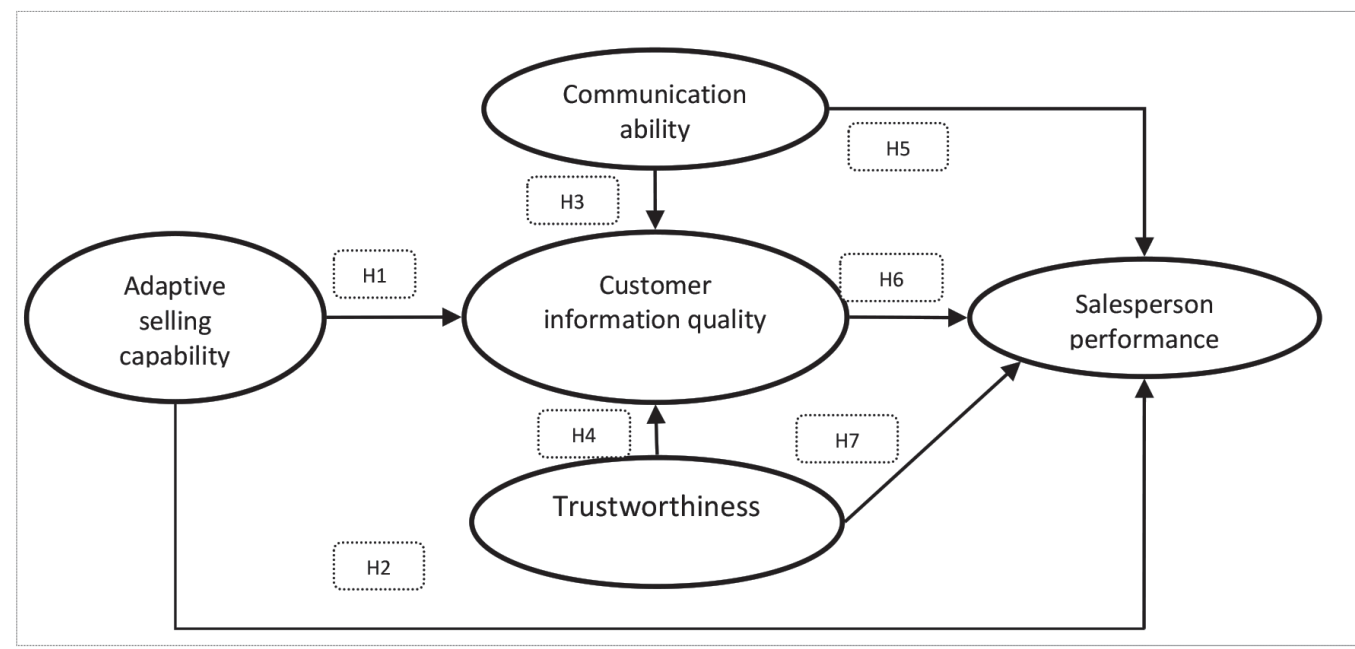


Using literature as the basis for gaining an understanding of these relationships, customer information quality is used to develop and test a model (Figure 1). We tested customer information quality as an intervening variable that helps explain how the adaptive selling capability may affect a salesperson's performance. Finally, we examined the effects of communication ability and trustworthiness coinciding with the salesperson's performance. An illustration of the hypothesized model is shown in Figure 1.

\section{HYPOTHESIS}

\subsection{Adaptive selling and customer information quality}

Customers have different characteristics that require different approaches (Locander, Mulki \& Weinberg, 2014; Singh \& Das, 2013), and it is important for salespersons to elicit information on customers' needs. Salespersons desperately need accurate information from customers as well. The accuracy and completeness of information from customers can determine the quality of information depending on the salespersons' abilities to understand the needs and demands of the customers. To search for an accurate and complete information from customers, salespersons can optimize the use of information technology (Khudri \& Sultana, 2015). Through the use of information technology, a salesperson can also achieve effectiveness and efficiency in gathering qualified information. The use of information technology process is simple, yet its accuracy is high. A simple process means that the information accessibility is practical; it may occur anywhere and anytime, even by using an Android application on the mobile phone. By using an Android smartphone, for example, a salesperson may get a variety of information from customers, such as their needs, preferences, etc. However, salespersons should also be able to take different approaches to respond to different customers, so that they can easily adapt to the varied needs of their customers. In other words, each salesperson is required to develop an adaptive behavior to help them obtain quality information from their customers.

The salesperson's ability to understand customers well is the key to success in building long-term relationships (Liang, Yongyue \& Chanwook, 2018). Customers who get good services will certainly feel satisfied. In addition, the salesperson must be able to maintain and develop good relationships with customers as a long-term investment and a mutually beneficial service. In doing so, consumers get the maximum satisfaction. In turn, customer satisfaction potentially provides information that has voluntary quality for the company's products and competing products. Information on the company's products may contain a weakness of the product that has been bought. Thus, the proposed hypothesis is stated, as follows:

H1: Adaptive selling can improve customer information quality.

\subsection{Adaptive selling and salesperson performance}

Salesperson should understand customers well (Amyx, Sharma \& Alford, 2014; Bolander et al., 2015; Miao \& Evans, 2013). A salesperson can understand the customers' needs and desires easily by conducting an experiment. Because each customer requires a distinct approach, such experiment requires patience and persistence; hence, a salesperson should have certain skills in carrying out the selling tasks (Piercy, Cravens \& Lane, 2012). The skills include the mastery of various approaches to sales. If an approach does not work well, a salesperson can easily replace it with a more appropriate approach within a contextual situation and actual conditions. Such action has the potential to improve the salesperson's performance.

The salesperson's abilities to adjust and interact with customers are likely to improve the selling performance (Yilmaz, 2001). Salespersons have to understand the customers' needs and desires as this will affect customer satisfaction. In turn, it can lead to a repeat purchase and the will- 
ingness of the customers to stay with a certain product. Loyal customers have an impact on increasing the companies' sales volume (Xiabing, Christy, Matthew \& Liang, 2015). In addition to repurchasing, customers will feel satisfied with the services, and will further recommend the product to friends and relatives. Indeed, higher sales volumes can boost company profits; increasing profits can, then, be used to improve the strategy for market share expansion. Thus, the following hypothesis can be proposed:

H2: Adaptive selling can improve salesperson performance.

\subsection{Communication ability and customer information quality}

A salesperson's ability to communicate effectively is one of the key factors to obtain quality information from customers (Kim \& Kim, 2016; Seyoon \& Jungwoo, 2014). The forms of communication may vary, namely conversations via telephone, electronic mails, and face-to-face communication platforms. Communication effectiveness can be measured through customers' response rates (Park, Lee \& Lee, 2014; Ponduri \& Bala, 2014). If a customer responds well, it means that the communication is effective. In addition, the quality of communication is of paramount importance. The more useful the communication, the better the response from the customer. Relevance and content in communication will greatly determine customer satisfaction (Park et al., 2014). It means that customers will be more satisfied when they get information relevant to their needs and preferences. In this way salespersons may have twofold benefits: getting quality information from the customers and building quality relations with them as well.

In addition, a good and structured communication tends to create better-quality relations with customers (Veenraj \& Ashok, 2014). Having good communication will surely lead to objective criticism. This objective point of view is of interest for the future betterment. The organizations that pay more attention to other parties have a better chance to develop professionally (Abdul-Hafez \& Al-Nady, 2016; Toyese, 2014). As a company needs to conduct a decision-making process, it requires good quality information that can be gathered by sales staff, especially those who have good communication skills. Hence, good communication skills need to be developed to facilitate better customer relations. This can be achieved by maintaining a long-term relationship and fulfilling the needs and desires of customers. Hence, the third proposed hypothesis can be formulated as follows:

H3: Communication ability is capable of improving customer information quality.

\subsection{Trustworthiness and customer information quality}

Trust is another important factor in maintaining the quality of information obtained from customers (Agnihotria \& Krush, 2015; Cheung et al., 2013; Yulin et al., 2014). Another salesperson's task is to build and maintain customers' trust, defined as the very strategic path towards maintain good relationships with customers that can improve the quality of information (Animesh, Pinsonneault, Yang \& Oh, 2011; Tsai, Chin \& Chen, 2010). Once customers' trust develops, the salesperson should have to maintain and develop their trust by providing assurances to customers for the product they have purchased. The ways of maintaining the quality of customer information can include providing warranty on the goods that have been purchased (Schwepker \& Good, 2012; Çerri, 2012), providing the best possible service, and being honest with customers. In addition, high integrity will determine the success of salespersons in sustain the quality of relationships with customers.

Trust further deals with increasing the openness of customers to the salesperson (Yulin et al., 2014), a process that takes quite a long time to establish. During the process of building their customers' trust, salespersons have a tough task, i.e. they must be honest to the customers. This honesty has a potential to increase the level of customer satisfaction (Cheung et al., 2013;

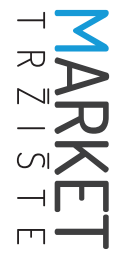


Çerri, 2012). Consequently, satisfied customers are able to provide very useful quality information to salespersons. Referring to such an analysis, the following hypothesis can be proposed:

H4: Trustworthiness can improve customer information quality.

\subsection{Communication ability and salesperson performance}

Good communication skills of the sales staff are one of the key success factors in meeting customers' needs and demands (Abdul-Hafez \& Al-Nady, 2016; Toyese, 2014). Quality communication can increase customer satisfaction that ultimately influences purchasing decisions. Interacting with customers regularly and systematically is a must for a salesperson (Kim \& Kim, 2016; Ponduri \& Bala, 2014). By having this interaction, there will be some information about the products that can be delivered effectively. Furthermore, the interaction with customers through a face-to-face approach would be very helpful for companies in their decision making (Yulin et al., 2014; Zieliński, 2013). Salespersons can use telephone, email, or other electronic media to establish communication with customers. Those methods will not only reduce costs but will also make their communication more efficient and effective. Efficient communication tends to improve their performance.

Salespersons have a critical role if selling performance is to be improved (Bolander et al., 2015; Pettijohn et al., 2014). The ability of salespersons to expand the network and build relationships with customers as much as possible is a very urgent and vital task to carry out. Broad and quality networks tend to support their performance, so selling performance continues to increase (Miao \& Evans, 2013; Piercy et al., 2012). A quality network of subscribers widens when it is accompanied by the ability of a salesperson to adapt while interacting with customers (Miao \& Evans, 2013). Salespersons who can apply a good approach to customers using interesting presentations will be able to make their customers satisfied. Consumers who are satisfied with the products they have purchased will make a re-purchase (Piercy et al., 2012). This increasing redistribution tends to improve the salesperson performance.

Salespersons should acquire quality communication skills if they want to improve their selling performance (Yilmaz, 2001; Park \& Deitzb, 2006). The accuracy of information intended for the customers is the key to establishing communication successfully. Salespersons who respond to customers' complaints quite well are able to meet customers' needs and demands to make them satisfied (Amyx et al., 2014). Moreover, they have the ability to provide information that is appropriate and useful to customers, and relevant and useful customer information has the potential to improve the selling performance. Increased sales are among the key indicators by which to measure the success of a salesperson (Basir et al., 2010). However, many indicators can also be used to determine salesperson performance; namely, increased market share, sales growth, increased profitability of the company, and fewer complaints by the customers. The ability to communicate well has the potential to improve the salesperson performance. Hence, the researchers proposed the following hypothesis:

H5: Communication ability can increase salesperson performance.

\subsection{Customer information quality and salesperson performance}

Quality information obtained from customers is evidently useful for the company (Setia et al., 2013). The company will find it helpful to obtain any information that can be used properly. It means that the company will set a strategy to use it (Nevo \& Wade, 2010; Ponduri $\&$ Bala, 2014). In fact, customers can re-purchase products. This re-purchase can improve selling performance that ultimately increases company profits. If this can be maintained, salesperson performance will possibly increase and it will in turn affect the employees' own welfare (Charles \& Schwepker, 2015; Xiabing et al., 2015). In this 
sense, the profits of a company can be reaped over a relatively long period of time thanks to the satisfaction of its customers. In addition, honestly provided information can help the company to determine what strategies can be used to best satisfy customers.

Salesperson performance is one of the main benchmarks that greatly determines the success of an organization (Miao \& Evans, 2013; Pettijohn et al., 2014; Piercy et al., 2012). Salespersons who can improve their sales performance can certainly improve the organizational performance. In this case, a salesperson's ability is the spearhead of the company's success. The organization leadership should pay close attention to the conditions of its salespersons (Amyx et al., 2014; Basir et al., 2010; Piercy et al., 2012). The leaders' attention should focus on rewards that are directly proportional to related achievements.

Salespersons who can work well are supposed to get better rewards rather than other salespersons who underperform. This must be sustainable, so that salespersons who excel will be motivated to perform better (Ahearne \& Jones, 2008; Cross \& Brashear, 2007; Park \& Deitzb, 2006). Another option is for organizational leaders to encourage salespersons to be more professional through regular and systemic training (Yilmaz, 2001). A dynamic and changing environment quickly forces leaders to conduct this training, so that salesperson can follow and anticipate the development of the environment properly.

Quality information from customers can improve salesperson performance (Hajli \& Lin, 2016). Thus, accurate customer information is required. The information on customers' desires is an important aspect that the company has not fulfilled. Besides, establishing long-term mutually beneficial relationships is an investment that has the potential to improve sales performance. Thus, the following hypothesis is proposed:

H6: Customer information quality can increase salesperson performance.

\subsection{Trustworthiness and salesperson performance}

Customers' safety is a key consideration in relation to the sales staff (Agnihotria \& Krush, 2015; Yulin et al., 2014). Customers who feel secure in conducting a transaction will not hesitate to spend money to make any transactions with a salesperson. The salespersons' job is, thus, to build and maintain their customers' trust. This can be built by providing the best possible service and paying attention to the customers' needs and demands (Tsai et al., 2010). Companies should consistently disseminate true information about their products to the customers, as misleading information can cause disappointment to their customers. To anticipate the recurrence of this information, honesty to customers is the best policy, for example, by building up customers' trust (Cheung et al., 2013; Çerri, 2012). Honesty is a gateway to the provision of precise and accurate information about products, in particular, the superiority of products and the proper use of products. The customers' trust should remain consistent in maintaining the quality of products and services that can affect the selling performance.

One of the ways to improve the selling performance is through increased market share (Basir et al., 2010; Park \& Deitzb, 2006; Piercy et al., 2012). Some companies expand their market share. Further, the expansion of customers' networks is an effective way to increase market shares. Through a vast network of information on the customers' needs and demands, products' outstanding profiles can be known more quickly. Communication occurs through a wide variety of customers' networks that can improve the effectiveness and efficiency of communication with customers and reduce the incorrect information on the products (Ahearne \& Jones, 2008; Park \& Deitzb, 2006). Broad networks can increase the intensity of communication with customers. Sales targets can be met if they are fully supported by a wide variety of customers' networks (Yilmaz, 2001). Therefore, through a wide variety of networks the salesperson performance can be improved. 
Customers' trust has a positive impact on the salesperson performance (Cheung et al., 2013). Customers who trust the company's products tend to repurchase. Moreover, they tend to invite and influence others to do the same thing. For customers who have gained satisfaction with the product they bought, it is difficult to switch to competing products, even though there are attractive offers from competing products. The customers who make repeat purchases can improve sales performance that, in turn, increases company's profits. Thus, the next proposed hypothesis is formulated as follows:

H7: Trustworthiness is able to increase salesperson performance

\section{RESEARCH METHODOLOGY}

\subsection{Sample frame and data collection}

The Indonesian health insurance sector was selected as the research object because public awareness of health in Indonesia is extremely high. This can be seen from an increasing number of participants in health insurance every year. Furthermore, the number of hospitals and public health services also keeps increasing annually.

The ability of a salesperson to explain health products can help customers make decisions before purchasing those products. This ability is required to understand customers' needs well. Thus, professional services should be provided through a wide variety of approaches for different customers. An adaptive approach is fundamentally applied if one of the initial approaches does not work well. Professional sales staff can overcome the customers' difficulties in terms of adaptable conditions or circumstances and they have to understand customer behavior (Chakrabarty, Brown \& Widing II, 2013; Teece, 2014). Furthermore, salespersons are required to understand the products knowledge well. The mastery of products knowledge is an im- portant factor that determines the success of selling (Dulger, Alpay, Yilmaz \& Bodur, 2016; Zhu \& Chang, 2015).

This research covered a number of insurance companies in Indonesia. The data were collected using questionnaires among their sales staff as respondents from January to June 2017. The unit of analysis was a salesperson offering health insurance policies in Yogyakarta, Indonesia. The purposive sampling method was employed to select the respondents with a minimum 5 years' work experience in the selling of insurance policies. The age of respondents was set to be at least 17 years, and their minimum education at senior high school level. A total of 400 respondents had a $91 \%$ return rate. Following the data collection, the questionnaires were tested for validity, reliability, non-response bias, and logical connection (Ferdinand, 2014).

\subsection{Measurement}

The scale employed by the authors was inspired by previous relevant studies. Measurement scale is intended as a method to quantify variables and is employed in measuring the data. The data obtained through questionnaires are ordinal scales. The questionnaire was developed on the basis of relevant research variables and critical review of the concepts of relationship marketing.

We measured adaptive selling behavior using 3 items adapted from Chena and Jaramillob (2014), for example, "I use different approaches for different customers."

We measured customer information quality using 4 items adapted from Agnihotria, Vieirab, Senrab and Gablerc (2016), Park and others (2014), for example, easily develop long-term relationships with customers."

Salesperson performance was measured using 3 items adapted from Abed and Haghighi (2009), Schwepker and Schultzb (2015), for example, "I have exceeded the sales targets set by the company." 
We measured trustworthiness using 3 items adapted from Pousa and Mathieu (2014), for example "I emphasize the significance of customer satisfaction."

Communication ability was measured using 3 items adapted from Dulger and others (2016) and Hassan, Quershi, Hasnain, Sharif and Hassan (2013), for example, "The information provided by him/her was very useful for my work."

A small number of data samples were used for a pre-test carried out to test the validity of the questionnaire and its indicators. The data test was performed using the non-response bias technique, validity, and reliability tests. The tests were continuously conducted until all the data met both the validity and reliability criteria, since a valid and reliable questionnaire would be able to capture good and correct data. Thus, the questionnaire was found to be feasible and reliable for collecting research data. The 10-point Likert scale included a range from 1 (strongly disagree) to 10 (strongly agree) to measure all the variables of indicators.

\section{RESULTS}

\subsection{Validity and reliability}

A prior test applied on the questionnaire revealed that all the items were valid and reliable, showing indications of all loading values. The average extracted variance, convergent validity, and discriminant validity was greater than 0.6 (as shown in Table-1).

The structural equation modeling (SEM) method elements, namely the fulfillment of SEM assumptions, confirmed the assumption of normality of the research data. As seen from the value of the critical ratio $(C R)$, with no value at \pm 2.58 , the data could be said to be normal. The second element was the evaluation of outliers.
Outliers can be investigated by comparing the chi-square value of the table with the Mahalanobis distance; the AMOS output showed no observation of numbers greater than the chisquare value. The chi-square value could be calculated from the number of items $=20$, and significant level of $a=1 \%$, giving the chi-square value of 43.315; no multivariate outlier was detected. The third element was checking for multicollinearity and singularity in a combination of variables. The value of determinants of very small covariance matrices indicates the presence of multicollinearity (Tabachnick \& Fidel, 1996). From the Amos output, it was known that the determinant of sample covariance matrix = 0.108 . Thus, it can be concluded that there was no multicollinearity.

\subsection{Confirmatory factor analysis and construct validity}

The model feasibility evaluation was undertaken to confirm the hypothesized model according to the sample data. The model feasibility evaluation refers to some of the following selected criteria (Hair, Black, Babin \& Anderson, 2010). Indicators that have loading factors below 0.50 were dropped. The statistical models are declared fit and can be accepted if they have the value of $X 2=77.236$; Prob. .895; $d f=94 ; p$ $<.894 ; \mathrm{RMSEA}=.000 ; \mathrm{CFI}=1,000 ; \mathrm{AGFI}=.924 ; \mathrm{GFI}$ $=.948 ; \mathrm{NFI}=.968$. While the overall $X 2$ is significant, the $\mathrm{X} 2 \mathrm{~d}$ df ratio $=.822$.

The researchers, then, assessed the convergent and discriminant validity. The convergent and internal validity actually measured the constructs that should theoretically be measured. This was achieved through an analysis of reliability. Each construct has a Cronbach alpha above 0.75 (Hair et al., 2010). All the constructs, loading factors, the composite reliability and the average variance extracted (AVE) are presented in Table 1.

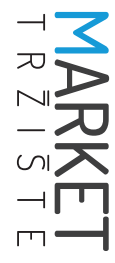


TABLE 1: Scale items and loading factors, CR and AVE

Constructs

Standardized

Adaptive selling behavior (Chena \& Jaramillob, 2014) AVE $=.526$; Composite

Reliability $=.816$

When I feel my approach does not work, then I can easily change with other

.838 approaches.

I use different approaches for different customers.

I can easily solve customers' problems. loadings

Customer information quality (Agnihotria et al., 2016; Park et al., 2014) AVE = .514; Composite Reliability $=.834$

I always think of the long-term benefits for customers who buy my products.

I think that customers spend more time [deciding on] a long-term investment.

I am interested in maintaining long-term sales relationships.

I easily develop long-term relationships with customers.

.710

.761

Salesperson performance (Abed \& Haghighi, 2009; Schwepker \& Schultzb, 2015) AVE $=.501$ Composite Reliability $=.750$

I always generate higher levels of sales compared to my colleagues.

I have exceeded the sales targets set by the company.

I have been able to increase company profits.

Trustworthiness (Pousa \& Mathieu, 2014), AVE=.561; Composite Reliability $=.793$

I emphasize the significance of customer satisfaction.

I emphasize the significance of customers' needs.

I am a good listener to customers.

Communication ability (Dulger et al., 2016; Hassan et al., 2013) AVE=.629;

Composite Reliability $=.829$

The information provided by him/her was very useful for my work.

I was very satisfied with the content of the information provided by him/her.

The information provided by him/her was highly relevant to my work.

.953

.931

.943

.937

\subsection{Parameters of value estimation}

Figure 2 shows that adaptive selling has a significant positive effect on salesperson performance through customer information quality. In addition to the adaptive selling technique,

communication ability and trustworthiness also have a significant positive effect on the customers' networking quality and salesperson performance. Thus, the role of the customer information quality variable is a key factor for improving salesperson performance. 


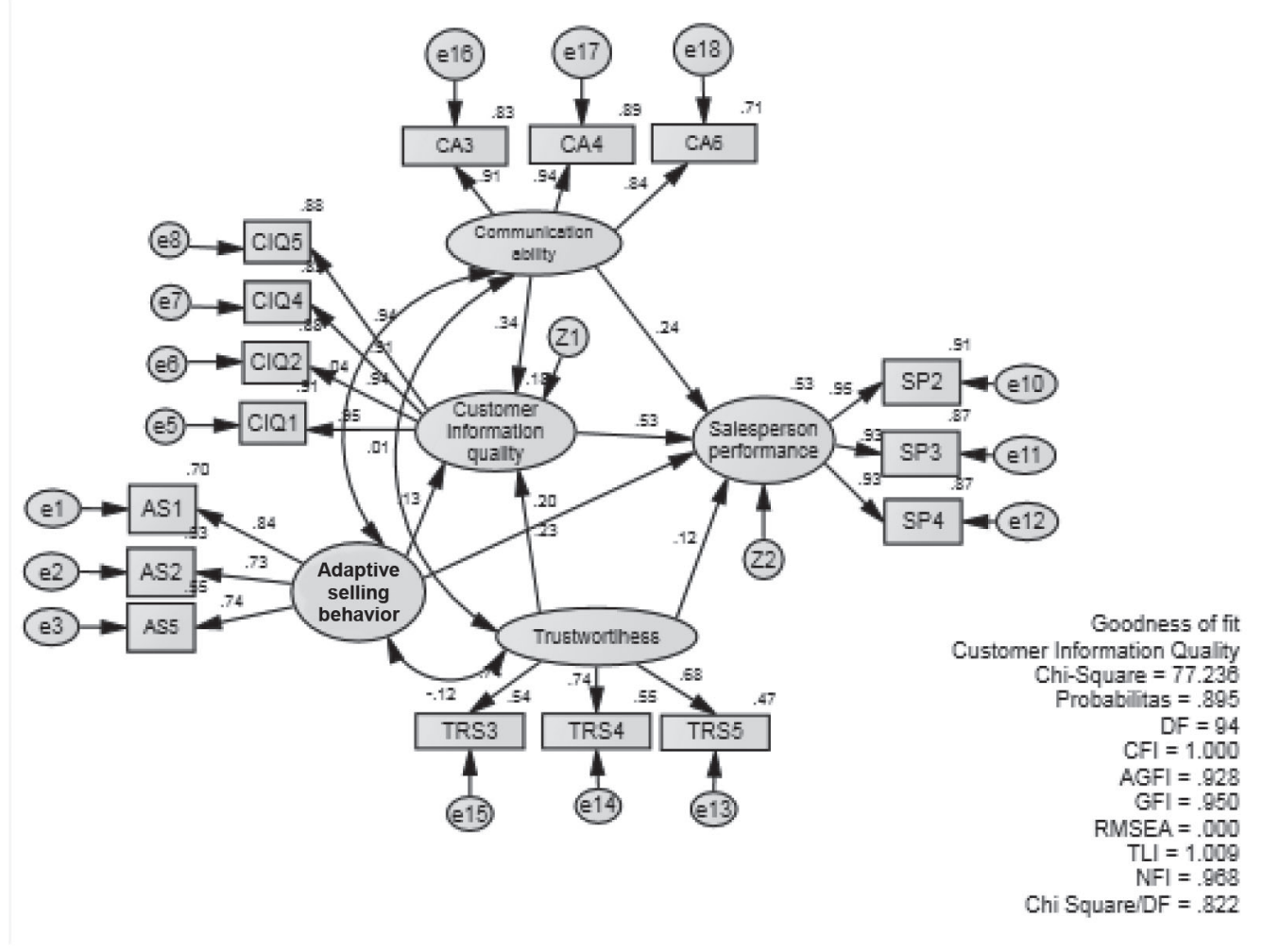

\subsection{Hypothesis testing}

The hypothesis testing can be viewed from the results of the standardized coefficient regression. The estimation results are presented in Table 2.
The adaptive selling was found to have a significant positive effect on customer information quality, with the standardized coefficient of .182 and the probability value of .011 (Hypothesis 1) Meanwhile, adaptive selling proved not to have

TABLE 2: Standardized regression weights: (Group number 1 - Default mode)

\begin{tabular}{|l|l|c|l|c|c|c|}
\hline & \multicolumn{1}{|c|}{ Path } & & & $\boldsymbol{\beta}$ & Sig & Comment \\
\hline H1 & Customer information quality & $\leftarrow$ & Adaptive selling behavior & .13 & .133 & Rejected \\
\hline H2 & Salesperson performances & $\leftarrow$ & Adaptive selling behavior & .20 & .002 & Accepted \\
\hline H3 & Customer information quality & $\leftarrow$ & Communication ability & .31 & ${ }^{* * *}$ & Accepted \\
\hline H4 & Customer information quality & $\leftarrow$ & Trustworthiness & .23 & .011 & Accepted \\
\hline H5 & Salesperson performance & $\leftarrow$ & Communication ability & .24 & ${ }^{* * *}$ & Accepted \\
\hline H6 & Salesperson performance & $\leftarrow$ & $\begin{array}{l}\text { Customer information } \\
\text { quality }\end{array}$ & .53 & $* * *$ & Accepted \\
\hline H7 & Salesperson performance & $\leftarrow$ & Trustworthiness & .12 & .061 & Rejected \\
\hline
\end{tabular}

$N=259 ;{ }^{*} p<.05 ;{ }^{* *} p<.01 ;{ }^{* * *} p<.001$. 


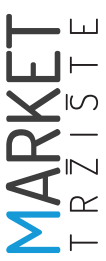

an effect on salesperson performance, showing the standardized coefficient of .109 and the probability value of .091 (Hypothesis 2). Customer orientation was found to have a significant positive effect on the selling relationship quality, with the standardized coefficient of .318 and the probability value of .000 (Hypothesis 3). The learning orientation also has a significant positive effect on the selling relationship quality, having the standardized coefficient of .296 and the probability value of .000 (Hypothesis 4). Customer orientation was found to have a significant positive effect on salesperson performance, displaying the standardized coefficient of .227 and the probability value of .000 (Hypothesis 5). The selling relationship quality also has a positive significant effect on salesperson performance, with the standardized coefficient of .531 and the probability value of .008 (Hypothesis 6). The learning orientation has a significant positive effect on salesperson performance as well, having the standardized coefficient of .187 and the probability value of .008 (Hypothesis 7). In sum, from the total of seven hypotheses proposed in this study, five hypotheses were statistically accepted, while two were rejected.

\subsection{Testing a mediating role: customer information quality}

Testing for the importance of the customer information quality role is considered a new concept in overcoming the adaptive selling gap of salesperson performance. This can be done using Sobel's test calculations. The Sobel test is used to assess the significance of indirect effects or the effect of mediation in a structural equation model. The result of the calculation is available online at http://www.danielsoper.com.

The Sobel test calculator was applied to test the significance of moderation variables, as presented in Figure 4.2. It explains that the customer information quality plays a significant role as a mediator in bridging the gap between adaptive selling and salesperson performance. This is evident from the Sobel test value of 2.661 with a probability value (two sides) that is equal to 0.007. Then, the second line is 2.561 with a probability value (two sides) that equals 0.006 , whereas this value is below 0.05. Next, the third line is 2.44 with a probability value (two sides) equal to 0.007 . Thus, the results of the significance test confirm that the customer information quality variable is a mediator between adaptive selling and salesperson performance.

\section{DISCUSSION}

The results of this study showed that a salesperson's communication abilities are the most important element influencing customer information quality; it can be seen from its beta coefficient of .31, with a significance value of 0.000 . It indicates that it is essential for sales staff to always improve them, especially when providing information beneficial to their customers. Good communication skills will also ensure that any information given to customers is of good quality and relevant. Moreover, another construct that highly influences salesperson performance is customer information quality. To improve it, it is also necessary to develop, maintain, and enhance a long-term, mutually beneficial relationship with customers, as this can be a long-term investment for a company.

Adaptive selling behavior has no effect on customer information quality, as proven by its beta value of 0.122 and significance of 1.33. This could be due to the incapability of the salesperson to adapt to different customers; however, the situation could be improved by choosing a more adaptive approach during the interaction with customers. Nevertheless, the result of this study was in accordance with the research conducted by Chena and Jaramillob (2014), who found that the adaptive selling has no effect on customer information quality. The researchers state that even salespersons who can adapt well when interacting with customers do not necessarily get the information that is expected. Thus, many factors need to be considered when obtaining information from customers. Another study 
(Singh \& Das, 2013) indicated that salespersons who can adapt when interacting with customers have a significant positive effect on customer information quality. Salespersons are, hence, supposed to overcome difficulties that might be encountered by customers by providing quality information. It means that the sales staff should be more flexible and use appropriate approaches when interacting with customers. This is crucial as each customer has distinctive characteristics that require a specific approach. Furthermore, presentation materials provided to the sales staff should also be of good quality and updated. Salespersons need to deliver their product knowledge in such a way that is likely to affect customers' interest in and decision to buy the products offered. The clearer the information, the better the customers' understanding of it. The customers who understand the information well will be able to make decisions easily.

Communication ability also affects customer information quality, as shown by its beta value of 0.31 and significance value of 0.002 . While the communication skills of salespersons are considered to be good enough and reliable, they still need further improvement. The ability of salespersons to provide quality information to customers is crucial, as high-quality information is very helpful for customers when making decisions. In addition, relevant information presented by salespersons must also meet the customers' needs and expectations. If the information is irrelevant, the customers will feel disappointed. The customers receiving relevant information will make more purchasing decisions. Therefore, the information relevant to customers' needs is very significant for the customers to make purchasing decisions. It is similar to the result of the research conducted by Fernando, Shaharudin and Wahid (2016), who found that the quality information, relevant information, or customer-friendly information has a significant positive effect on the customers' purchasing decisions.

The adaptive selling behavior variable affects salesperson performance through customer information quality. Hence, adaptive selling behavior can only affect salesperson performance if there is a factor of customer information quality involved. In this case, the role of the customer information quality variable is very meaningful for improving salesperson performance. Salespersons are regarded as being adaptive when they are able to apply different approach to distinct customers as well as being adaptive to any changing needs. When an approach does not work well, salespersons can still understand customers and overcome their difficulties by switching to a more appropriate approach. Thus, without considering customer information quality, the performance of salespersons cannot be easily improved.

Customer information quality is a variable that has the largest contribution among other antecedent variables, such as the communication ability variable, trustworthiness, and adaptive selling behavior, when it comes to the improvement of salesperson performance. The role of customer information quality is crucial; increasing it will lead to an increase in salesperson performance. Even adaptive selling behavior will not have a significant impact on salesperson performance if it does not take into account customer information quality. Therefore, it is expected that salespersons must place customer information quality first, as it is a principal variable to improve salesperson performance.

\section{CONCLUSION}

Customer information quality is influenced by the communication ability, trustworthiness, and adaptive selling behavior. Therefore, salespersons should develop a better relationship with their customers to get quality information. Their successful relationship is characterized by building good relations, developing long-term mutual benefits, and considering customers' needs and desires, where all of those are considered as a long-term investment. Customers will provide quality information to the sales staff when the sales staff also provides quality

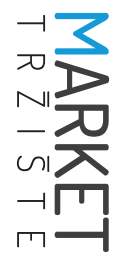


information to them. This quality and relevant information helps customers to easily make purchasing decisions. Hence, salespersons who adapt well when interacting with customers will effortlessly sell products and get quality information from customers. In addition, the ability of salespersons to understand the customers' needs and desires is a key to maintaining a high level of success in obtaining quality information from customers.

Salesperson performance can, therefore, be improved since it is influenced by customer information quality, communication ability, trustworthiness, and adaptive selling behavior. In addition, increased customers' confidence will improve the performance of the sales staff. Customer satisfaction leads to a re-purchasing of the products; the customers who feel contented with the level of service delivered by the salesperson are satisfied because their needs and desires are well provided for. To understand customers' needs and desires, salespersons must be good and sincere listeners to customers. A good listener can not only give comments as needed but will also understand customers' feelings and provide solutions to customers' problems. If salespersons can do this well, their sales volume may increase; increased sales in turn mean increased profits. In fact, as increased profits go hand in hand with market expansion, salesperson performance becomes tremendously high.

\section{MANAGERIAL IMPLICATIONS}

Salespersons can improve their qualifications through trainings and by reading articles that are relevant to selling and focus on consumers' tastes that change dynamically. Besides, salespersons need to improve their new selling strategies; for example, those that build and optimize emotional bonds to improve their performance. Moreover, they also need to pay attention to customers' needs by providing appropriate and timely services.
Customer information quality can be developed by improving communication capabilities. Salespersons need to focus on improving communication skills by providing available, sufficient, and relevant information to support their tasks. The customer information quality can also be obtained by building the customers' trust, which salespersons can do through an emphasis on maintaining a high level of satisfaction of their customers, by paying attention to their needs, and being a good listener to them. Thus, salesperson performance can be improved by developing their ability to adapt when interacting with their customers by using different approaches in the interaction with different customers, by being able to provide solutions to the customers' problems, and to easily change an approach that is simply not working. Likewise, salespersons need to constantly improve their performance through maintaining a longterm relationship with their customers, as this is also considered to be a long-term investment for their company. Through such a relationship, salespersons can ensure obtaining good quality information from their customers and can, thus, improve their own performance.

\section{LIMITATIONS AND FUTURE RESEARCH}

The quality of data really determines research performance; to get maximum research performance, the data should be analyzed not only from the perspective of the sales staff, but also from the perspective of sales managers. When data from both these sides are introduced in a research study, more accurate results can be obtained. The research itself should be conducted longitudinally, instead of merely on a cross-section. By employing these two strategies, more complete data can be obtained. With regard to research variables, in addition to salesperson performance, the focus should be expanded to also reflect the continuance organizational commitment capability.

The directions for future research in this field can be viewed in terms of product categories. 
Since adaptive selling variables have no significant effect on customer information quality, two other non-significant variables need to be tested on different product categories, specifically those with low involvement. In addition, the trustworthiness variable does not have a significant effect on salesperson performance. However, it is necessary to evaluate its indicators, especially in the statements: "I emphasize the significance of customer satisfaction", and "I emphasize the significance of customers' needs". The adaptive selling strategy does not appear to have a significant effect on customer information quality; thus, other variables that are presumed to potentially increase the customer information quality may be considered by researchers for further examination. For example, one may opt to include the variable of customers relationship management (Tawinunt et al., 2015). Other possible research may also examine how adaptive selling influences negative organizational deviant behavior (Amyx \& Jarrell, 2016) as its dependent variable.

\section{References}

1. Abdul-Hafez, B., \& Al-Nady, A. (2016). The role of time, communication, and cost management on project management success: an empirical study on sample of construction projects customers in Makkah City, Kingdom of Saudi Arabia. International Journal Services and Operations Management, 23(1), 76-113.

2. Abed, G. M., \& Haghighi, M. (2009). The effect of selling strategies on sales performance. Business Strategy Series, 10, 266-228.

3. Adewale, A. A., Yusuf, M. B. O., Mat Ghani, G., Meera, A. K. M., \& Manap, T. A. A. (2012). The Role of Institutional Trust in the Adoption of Gold Dinar in Klantan: An Empirical Analysis. Journal of Applied Science, 12(20), 2148-2155.

4. Agnihotria, R., \& Krush, M. T. (2015). Salesperson empathy, ethical behaviors, and sales performance: the moderating role of trust in one's manager. Journal of Personal Selling \& Sales Management, 35(2), 164-174.

5. Agnihotria, R., Vieirab, V. A., Senrab, K. B., \& Gablerc, C. B. (2016). Examining the impact of salesperson interpersonal mentalizing skills on performance: the role of attachment anxiety and subjective happiness. Journal of Personal Selling \& Sales Management, 36(2), 174-189.

6. Ahearne, M., \& Jones, E. (2008). High Touch Rough High Tech: The Impact Of Salesperson Technology Usage On Sales Performance Via Mediating Mechanisms. Management Science, 54(4), 671-685.

7. Ahearne, M., Gruenb, T. W., \& Jarvisc, C. (1999). If looks could sell: Moderation and mediation of the attractiveness effect on salesperson performance. International Journal of Research in Marketing, 16(4), 269-284.

8. Amyx, D., Bhuian, S. N., \& Shows, G. D. (2016). Customer-salespeople relationship: Influence of salespeople entrepreneurial behaviours. Marketing Intelligence \& Planning, 34(5), 586-604.

9. Amyx, D., \& Jarrell, L. (2016). The Influence of Salesperson Depression, Low Performance, and Emotional Exhaustion on Negative Organizational Deviance. Journal of Managerial Issues, 27(3/4), 127-144.

10. Amyx, D., Sharma, D., \& Alford, B. L. (2014). The Influence Of Role Ambiguity And Goal Acceptance On Salesperson Performance And Commitment. Marketing Management Journal, 24(1), 5265.

11. Animesh, A., Pinsonneault, A., Yang, S-B., \& Oh, W. (2011). An Odyssey Into Virtual Worlds: Exploring The Impacts Of Technological And Spatial Environments On Intention To Purchase Virtual Products. MIS Quarterly, 35(3), 789-810. 
12. Babakus, E., Cravens, D. W., Grant, K., Ingram, T. N., \& LaForge, R. W. (1996). Investigating the relationships among sales, management control, sales territory design, salesperson performance, and sales organization effectiveness. International Journal of Research in Marketing, 13(4), 345-363.

13. Basir, M. S., Ahmad, S. Z., \& Kitchen, P. J. (2010). The relationship between sales skills and salesperson performance: An empirical study in the Malaysia Telecommunications Company. International Journal of Management and Marketing Research, 3(1), 51-73.

14. Behrman, D. N., \& Perreault, W. D. (1982). Measuring the performance of industrial salespersons. Journal of Business Research, 10(3), 355-370.

15. Bolander, W., Satornino, C. B., Hughes, D. E., \& Ferris, G. R. (2015). Social Networks Within Sales Organizations: Their Development and Importance for Salesperson Performance. Journal of Marketing, 79, 1-16.

16. Brown, S. P., \& Peterson, R. A. (1994). The effect of effort on sales performance and job satisfaction. Journal of Marketing, 58, 70-80.

17. Chai, J., Zhao, G., \& Babin, B. J. (2012). An empirical study on the impact of two types of goal orientation and salesperson perceived obsolescence on adaptive selling. Journal of Personal Selling and Sales Management, 32(2), 261-273.

18. Chakrabarty, S., Brown, G., \& Widing II, R. E. (2013). Distinguishing Between the Roles of Customer-Oriented Selling and Adaptive Selling in Managing Dysfunctional Conflict in Buyer-Seller Relationships. Journal of Personal Selling \& Sales Management, 33(3), 245-260.

19. Charles, H., \& Schwepker, J. (2015). Influencing the salesforce through perceived ethical leadership: the role of salesforce socialization and person-organization fit on salesperson ethics and performance. Journal of Personal Selling \& Sales Management, 35(4), 292-313.

20. Chen, I. J., \& Popovic, K. (2003). Understanding customer relationship management people, process and technology. Business Process Management Journal, 9(5), 672-688.

21. Chena, C-C., \& Jaramillob, F. (2014). The double-edged effects of emotional intelligence on the adaptive selling - salesperson-owned loyalty relationship. Journal of Personal Selling \& Sales Management, 34(1), 33-50.

22. Cheung, S. O., Yiu, T. W., \& Lam, M. C. (2013). Interweaving Trust and Communication with Project Performance. Journal of Construction Engineering and Management, 139(8), 941-950.

23. Chuang, S-H., \& Lin, H-N. (2013). The roles of infrastructure capability and customer orientation in enhancing customer-information quality in CRM systems: Empirical evidence from Taiwan. International Journal of Information Management, 33(2), 271-281.

24. Cross, M. E., \& Brashear, T. G. (2007). Customer orientation and salesperson performance. European Journal of Marketing, 41(7/8), 821-835.

25. Çerri, S. (2012). Exploring Factor Affecting Trust And Relationship Quality In A Supply Chain Context. Journal of Business Studies Quarterly, 4(1), 74-90.

26. Drollinger, T., \& Comer, L. B. (2012). Salesperson's listening ability as an antecedent to relationship selling. Journal of Business \& Industrial Marketing, 28(1), 50-59.

27. Dulger, M., Alpay, G., Yilmaz, C., \& Bodur, M. (2016). How does learning orientation generate product innovativeness and superior firm performance?. International Journal of Business and Economic Development, 4(2), 68-77.

28. Erikssona, K., Bergströma, S., Carlssona, E., \& Harteliusa, L. (2014). Aspects of rating communicative interaction: Effects on reliability and agreement. Journal of Interactional Research in Communication Disoder, 5(2), 245-267.

29. Ferdinand, A. T. (2014). Structural Equation Modeling in Management Research. Fakultas Ekonomi UNDIP: Semarang. 
30. Fernando, Y., Shaharudin, M. S., \& Wahid, N. A. (2016). Eco-innovation practices: a case study of green furniture manufacturers in Indonesia. International Journal Services and Operations Management, 23(1), 43-58.

31. Gelle, E., \& Karhu, K. (2003). Information quality for strategic technology planning. Industrial Management \& Data Systems, 103(8), 633-643.

32. Gillis, C., Pitt, L., Robson, M. J., \& Berthon, P. (1998). Communication in the salesperson/customer dyad: an empirical investigation. Marketing Intelligence \& Planning, 16(2), 100-106.

33. Guenzi, P., De Luca, L. M., \& Spiro, R. (2016). The combined effect of customer perceptions about a salesperson's adaptive selling and selling orientation on customer trust in the salesperson: a contingency perspective. Journal of Business \& Industrial Marketing, 31(4), 553-564.

34. Hair, J., F., J., Black, W. C., Babin, B. J., \& Anderson, R. E. (2010). Multivariate Data Analysis Boston, MA: Pearson Prentice Hall.

35. Hajli, N., \& Lin, X. (2016). Exploring the Security of Information Sharing on Social Networking Sites: The Role of Perceived Control of Information. Journal of Business Ethics, 133, 111-123.

36. Hassan, M. U., Qureshi, S. U., Hasnain, A., Sharif, I., \& Hassan, R. (2013). Market Orientation, Learning Orientation And Organizational Performance: Evidence From Banking Industry Of Pakistan. Science Internastional, 25(4), 945-956.

37. Hu, J., Huang, K-T., Kuse, J., Su, G-W., \& Wang, K-Y. (1997). Customer information quality and knowledge management: A case study using knowledge cockpit. Journal of Knowledge Management, 1(3), 225-236.

38. Khudri, M. M., \& Sultana, S. (2015). Determinants of service quality and impact of service quality and consumer characteristics on channel selection. British Food Journal, 117(8), 2078-2097.

39. Kidwell, B., McFarland, R. G., \& Avila, R. A. (2007). Perceiving Emotion In The Buyer-Seller Interchange: The Moderated Impact On Performance. Journal of Personal Selling \& Sales Management, 32(2), 119-132.

40. Kim, B., \& Kim, S. (2016). Effects of managers' communication and satisfaction on their perceived importance of value chain sustainability. International Journal of Services and Operations Management, 25(1), 21-47.

41. Kim, J., \& Kim, J-E. (2014). Making customer engagement fun: Customer-salesperson interaction in luxury fashion retailing. Journal of Fashion Marketing and Management, 18(2), 133-144.

42. Lee, Y. J., \& Dubinsky, A. J. (2017). Consumers' desire to interact with a salesperson during e-shopping: development of a scale. International Journal of Retail \& Distribution Management, 45(1), 20 39.

43. Liang, L. I., Yongyue, Z. H. U., \& Chanwook, P. (2018). Leader-Member Exchange, Sales Performance, Job Satisfaction, and Organizational Commitment Affect Turnover Intention. Social Behavior \& Personality: An International Journal, 46(11), 1909-1922.

44. Limbu, Y. B., Jayachandran, C., Babin, B. J., \& Peterson, R. T. (2016). Empathy, nonverbal immediacy, and salesperson performance: the mediating role of adaptive selling behavior. Journal of Business \& Industrial Marketing, 31(5), 654-667.

45. Locander, D. A., Mulki, J. P., \& Weinberg, F. J. (2014). How do salespeople make decisions? The role of emotions and deliberation on adaptive selling, and the moderating role of intuition. Psychology \& Marketing, 31(6), 387-403.

46. Madnick, S., Wang, R. Y., Lee, Y. W., \& Zhu, H. (2009). Overview and framework for data and information quality research. ACM Journal of Data and Information Quality, 1(1), 1-22.

47. Markose, B. (2011). Influence of Moderators in the Relationship of Supervisory Feedback with Goal Orientation of Salespeople - An Empirical Study. International Journal of Business Insights and Transformation, 4(2), 53-66. 
48. Miao, C. F., \& Evans, K. R. (2013). The interactive effects of sales control systems on salesperson performance: a job demands-resources perspective. Journal of the Academy of Marketing Science, 41, 73-90.

49. Naylor, G., \& Frank, K. E. (2000). The impact of retail sales force responsiveness on consumers' perceptions of value. Journal of Service Marketing, 14(4), 310-322.

50. Nevo, S., \& Wade, M. R. (2010). The Formation And Value of It-Enabled Resources: Antecedents and Consequences of Synergistic Relationships. The Society for Information Management Quarterly, 34(1), 163-183.

51. Pankaj Setia, V. V., \& Joglekar, S. (2013). Leveraging Digital Technologies: How Information Quality Leads To Localized Capabilities And Customer Service Performance. MIS Quarterly, 37(2), 565-590.

52. Park, J-G., Lee, S., \& Lee, J. (2014). Communication effectiveness on IT service relationship quality. Industrial Management \& Data Systems, 114(2), 321-336.

53. Park, J. E., \& Deitzb, G. D. (2006). The effect of working relationship quality on salesperson performance and job satisfaction: Adaptive selling behavior in Korean automobile sales representatives. Journal of Business Research, 59, 204-213.

54. Pettijohn, C. E., Pettijohn, L. S., \& Keillor, D. B. (2000). Adaptive selling and sales performance: an empirical examination. Journal of Applied Business Research, 16(1), 91-111.

55. Pettijohn, C. E., Schaefer, A. D., \& Burnett, M. S. (2014). Salesperson Performance The Role of Role Ambiguity, Autonomy and Self-Efficacy. Academy of Marketing Studies Journal, 18(1), 99-111.

56. Piercy, N. F., Cravens, D. W., \& Lane, N. L. (2012). Sales Manager Behavior-Based Control and Salesperson Performance: The effects of Manager Control Competencies and Organizational Citizenship Behavior. Journal of Marketing Theory and Practice, 20(1), 7-22.

57. Ponduri, S. B., \& Bala, E. S. (2014). Role of Information Technology in Effective Implementation of Customer Relationship Management. Journal of Marketing \& Communication, 9(3), 50-55.

58. Pousa, C., \& Mathieu, A. (2014). Boosting customer orientation through coaching: a Canadian study. International Journal of Bank, 32 (1), 60-81.

59. Schwepker, C. H., \& Good, D. J. (2012). Sales Quotas: Unintended Consequences on Trust in Organization, Customer-Oriented Selling, and Sales Performance. Journal of Marketing Theory and Practice, 20(4), 437-452.

60. Schwepker, J. C. H., \& Schultzb, R. J. (2015). Influence of the ethical servant leader and ethical climate on customer value enhancing sales performance. Journal of Personal Selling \& Sales Management, 35(2), 93-107.

61. Setia, P., Venkatesh, V., \& Joglekar, S. (2013). Leveraging Digital Technologies: How Information Quality Leads To Localized Capabilities And Customerservice Performance. MIS Quarterly, 37(2), 565-590.

62. Seyoon, L., \& Jungwoo, L. (2014). Communication effectiveness on IT service relationship quality. Industrial Management \& Data Systems, 114(2), 321-336.

63. Simintiras, A. C., \& Cadogan, J. W. (1996). Behaviourism in the study of salesperson-customer interactions. Management Decision, 34(6), 57-64.

64. Singh, R., \& Das, G. (2011). The Moderating role of selling experience on the relationship between job satisfaction, adaptive selling behaviors, customer intention, and salesperson's performance. The proceding of the ANZMAC, 376.

65. Singh, R., \& Das, G. (2013). The impact of job satisfaction, adaptive selling behaviors and customer orientation on salesperson's performance: exploring the moderating role of selling experience. Journal of Business \& Industrial Marketing, 28(7), 554-564.

66. Singh, R., \& Koshy, A. (2010). Determinants of B2B salespersons' performance and effectiveness: A review and synthesis of literature. Journal of Business and Industrial Marketing, 25(7), 535-546. 
67. Spiro, R. L., \& Weitz, B. A. (1990). Adaptive selling: Conceptualization, measurement, and nomological validity. Journal of Marketing Research, 27(1), 61-69.

68. Tabachnick, B. G., \& Fidel, L. S. (1996). Using Multivariate Statistics. New York, NY: Harpoer Collings Colledge Publisher.

69. Tawinunt, K., Phimonsathien, T., \& Fongsuwan, W. (2015). Service Quality And Customer Relationship Management Affecting Customer Retention Of Longstay Travelers In The Thai Tourism Industry: A Sem Approach. International Journal of Arts \& Sciences, 8(2), 459-477.

70. Teece, D. J. (2014). A dynamic capabilities-based entrepreneurial theory of the multinational enterprise. Journal of International Business Studies, 45, 8-37.

71. Thomas, G. F., Zolin, R., \& Hartman, J. L. (2009). The Central Role Of Communication In Developing Trust And Its Effect On Employee Involvement. Journal of Business Communication, 46(3), 287-310.

72. Toyese, A. Y. (2014). Customer relationship management and customer loyalty in Nigerian telecommunication industry. Journal of Business and Retail Management Research, 8(2), 1-7.

73. Tsai, M-T., Chin, C-W., \& Chen, C-C. (2010). The effect of trust belief and salesperson's expertise on consumer's intention to purchase nutraceuticals: Applying the theory of reasoned action. Social Behavior and Personality: An International Journal, 38, 273-288.

74. Twing-Kwong, S., Albaum, L. G., \& Fullgrabe, L. (2013). Trust in customer-salesperson relationship in China's retail sector. International Journal of Retail \& Distribution Management, 41(3), 226-248.

75. Veenraj, P., \& Ashok, J. (2014). Impact Of Shopper Marketing On Purchase Decisions Of Information Technology Devices For Personal Use By Indian Consumers. Journal of Theoretical and Applied Information Technology, 64(3), 616-624.

76. Weitz, B. A., Sujan, H., \& Sujan, M. (1986). Knowledge, motivation, and adaptive behavior: A framework for improving selling effectiveness. Journal of Marketing, 50(4), 174-191.

77. Xiabing, Z., Christy, M. K. C., Matthew, K. O. L., \& Liang, L. (2015). Building brand loyalty through user engagement in online brand communities in social networking sites. Information Technology \& People, 28(1), 90-106.

78. Yao, Q., Chen, R., \& Cai, G. (2013). How internal marketing can cultivate psychological empowerment and enhance employee performance. Social Behavior and Personality: an International Journal, 41(4), 529-538.

79. Yilmaz, C. (2001). Salesperson Performance and Job Attitudes Revisited An Extended Model and Effects of Potential Moderators. European Journal of Marketing, 36(11/12), 1389-1414.

80. Yu, T-W., \& Tung, F-C. (2014). Antecedents and consequences of insurer-salesperson relationships. Marketing Intelligence \& Planning, 32(4), 436-454.

81. Yulin, F., Qureshi, I., Sun, H., McCole, P., Ramsey, E., \& Lim, K. H. (2014). Trust, Satisfaction, and Online Repurchase Intention: The Moderating Role of Perceived Effectiveness of e-Commerce Institutional Mechanisms. MIS Quarterly, 38(2), 407-427.

82. Zhou, H., \& Benton Jr., W. C. (2007). Supply chain practice and information sharing. Journal of Operations Management, 25(6), 1348-1365.

83. Zhu, D. H., \& Chang, Y. P. (2015). Effects Of Interactions And Product Information On Initial Purchase Intention In Product Placement In Social Games: The Moderating Role Of Product familiarity. Journal of Electronic Commerce Research, 16(1), 22-33.

84. Zieliński, M. (2013). The impact of misaligned business communication on the quality of salesperson - buyer relationships. Poznań University Of Economics Review, 13(2), 107-136. 